УДК $159.913+613.97(045)$

DOI https://doi.org/10.26661/2310-4368/2020-2-11

\title{
ПРИЧИННО-СИСТЕМНИЙ ХОЛІСТИЧНИЙ ПІДХД ДО ПРОБЛЕМИ ПСИХОСОМАТИЧНИХ ЗАХВОРЮВАНЬ
}

\author{
Одинець О. А. \\ здобувач магістратури психолого-педагогічного факультету \\ Комунальний заклад «Харківська гуманітарно-педагогічна академія» \\ Харківської обласної ради \\ пров. Руставелі, 7, Харків, Україна \\ Громадська спілка «Міжнародна наукова школа універсології» \\ вул. Люстдорфська дорога, 172, Одеса, Україна \\ лікар, керівник \\ «Школа холістичного здоров'я» \\ вул. Троїцька, 37, Дніпро, Украӥна \\ orcid.org/0000-0001-6575-0695 \\ ok.alisa@ukr.net
}

Шукалова О. С.

кандидат психологічних наук, дочент,

доиент кафедри педагогіки, психології, початкової освіти та освітнього менеджменту

Комунальний заклад «Харківська гуманітарно-педагогічна академія»

Харківської обласної ради

пров. Руставелі, 7, Харків, Україна

orcid.org/0000-0002-5127-3987

shukalova.o@gmail.com

Даніліч-Скакун А. А.

старший викладач кафедри педагогіки, психології,

початкової освіти та освітнього менеджменту

Комунальний заклад «Харківська гуманітарно-педагогічна академія»

Харківської обласної ради

пров. Руставелі, 7, Харків, Україна

orcid.org/0000-0003-1167-605X

danilichalla30@gmail.com

Нежута А. В.

кандидат психологічних наук,

старший викладач кафедри педагогіки, психології,

початкової освіти та освітнього менеджменту

Комунальний заклад «Харківська гуманітарно-педагогічна академія»

Харківської обласної ради

пров. Руставелі, 7, Харків, Украӥна

orcid.org/0000-0001-7528-0252

alinanezhuta26@gmail.com 
Хижняк М. В.

кандидат біологічних наук, доиент,

викладач кафедри педагогіки, психології, початкової освіти та освітнього менеджменту

Комунальний заклад «Харківська гуманітарно-педагогічна академія»

Харківської обласної ради

пров. Руставелі, 7, Харків, Україна

orcid.org/0000-0002-2650-4210

Khizhnyak.m@gmail.com

Ключові слова: психосоматика, семирівнева модель, холізм, причинно-системний холізм, універсологія, вищі мрї, повсякденні мрії, захворювання.
У статті розглядається сучасний міждисциплінарний холістичний підхід до людини як багатогранної та багаторівневої системи у разі розвитку психосоматичних захворювань. У роботі наведено дослідження причин виникнення психосоматичних захворювань через універсальну семирівневу модель, запропоновану новою міждисциплінарною наукою універсологією. Розглянуто взаємозв'язки психологічної самоактуалізації людини в семи сферах життя 3 формуванням захворювань опосередковано через вплив енергосистеми людини на ендокринні залози організму та вторинного впливу ендокринних залоз на пов'язані з ними системи та органи.

У статті наведено дослідження взаємозв'язку своєї оцінки семи сфер життя людини з наявністю захворювання, опосередковано пов' язаного зі сферою життя, і доведено статистично достовірний зв'язок між наявністю низької або завищеної оцінки людини в тій чи іншій сфері життя з наявністю захворювання, пов'язаного з цією сферою. У статті розглянуті поняття вищої мрії (як вищої цінності, сенсу життя, стимулюючої до духовного зростання, розкриття творчого потенціалу) і поняття повсякденної мрії - мрії-бажання, нереалізованої потреби людини на поточний момент, стимулюючої людину до реалізації мрії. Розглянуто мрії людини як потребу до реалізації в тій чи іншій сфері, у статті наведені дослідження взаємозв'язку мрії з наявністю захворювання, пов'язаного 3 тією чи іншою сферою життя, i статистично достовірно підтверджений взаємозв'язок виникнення психосоматичних захворювань від відсутності самореалізації людини у певній сфері життя.

Таким чином, дослідження, наведені у статті, відкривають новий погляд на причини психосоматичних захворювань, їх взаємозв'язок не тільки в цілісній холістичній системі організму і психіці людини, а також зв'язок людини зі своїми внутрішніми відчуттями і відчуттями зовнішнього світу через семирівневу модель життя. Крім того, цілісна система внутрішніх відчуттів та зовнішніх проявів людини має причинну частину у мріях людини, що дозволило сформувати таке нове поняття у сфері психосоматики, «як причинно-системний холізм». 


\title{
CAUSAL AND SYSTEM CHOLISTIC APPROACH TO THE PROBLEM OF PSYCHOSOMATIC DISEASES
}

\author{
Odynets O. A. \\ Master's degree Student at the Psychological and Pedagogical Faculty \\ Municipal Establishment "Kharkiv Humanitarian Pedagogical Academy" \\ of Kharkiv Regional Council \\ Rustaveli lane, 7, Kharkiv, Ukraine \\ Public Union "International Scientific School of Universology" \\ Lustdorfska doroha str., 172, Odessa, Ukraine \\ Doctor, Head \\ School of Cholistic Health \\ Troitska str., 37, Dnipro, Ukraine \\ orcid.org/0000-0001-6575-0695 \\ ok.alisa@ukr.net \\ Shukalova O. S. \\ Ph.D., Associate Professor, \\ Associate Professor at the Department of Pedagogy, Psychology, \\ Primary Education and Educational Management \\ Municipal Establishment "Kharkiv Humanitarian Pedagogical Academy" \\ of Kharkiv Regional Council \\ Rustaveli lane, 7, Kharkiv, Ukraine \\ orcid.org/0000-0002-5127-3987 \\ shukalova.o@gmail.com \\ Danilich-Skakun A. A. \\ Senior Lecturer at the Department of Pedagogy, Psychology, \\ Primary Education and Educational Management \\ Municipal Establishment "Kharkiv Humanitarian Pedagogical Academy" \\ of Kharkiv Regional Council \\ Rustaveli lane, 7, Kharkiv, Ukraine \\ orcid.org/0000-0003-1167-605X \\ danilichalla30@gmail.com \\ Nezhuta A. V. \\ Ph.D., \\ Senior Lecturer at the Department of Pedagogy, Psychology, \\ Primary Education and Educational Management \\ Municipal Establishment "Kharkiv Humanitarian Pedagogical Academy" \\ of Kharkiv Regional Council \\ Rustaveli lane, 7, Kharkiv, Ukraine \\ orcid.org/0000-0001-7528-0252 \\ alinanezhuta26@gmail.com
}




\author{
Khyzhniak M. V. \\ Ph.D. of Biological Sciences, Associate Professor, \\ Lecturer at the Department of Pedagogy, Psychology, \\ Primary Education and Educational Management \\ Municipal Establishment "Kharkiv Humanitarian Pedagogical Academy" \\ of Kharkiv Regional Council \\ Rustaveli lane, 7, Kharkiv, Ukraine \\ orcid.org/0000-0002-2650-4210 \\ Khizhnyak.m@gmail.com
}

Key words: psychosomatics, seven-level model, cholism, causal and system cholism, universology, higher dreams, everyday dreams, diseases.
The article deals with the modern interdisciplinary cholistic approach to the person as multifaceted and multilevel system at development of psychosomatic diseases. The paper presents a study of the psychosomatic diseases' causes through the universal seven-level model proposed by the new interdisciplinary science of universology. The interrelationships of psychological person's selfactualization in seven spheres of life with the formation of diseases, indirectly through the influence of the human energy system on the endocrine glands of the body and the secondary influence of endocrine glands on related systems and organs are considered.

The article presents a study of the relationship between its assessment of human's life seven areas with the presence of the disease. This disease is indirectly related to the sphere of life and proved a statistically significant relationship between the presence of low or inflated human assessment in a particular sphere of life with the presence of a disease associated with this sphere. The article considers the concept of a higher dream (as a higher value, the meaning of life, stimulating spiritual growth, creative disclosure) and the concept of everyday dreams - dreams and desires, unrealized human needs today stimulating a person to realize a dream. Considering human dreams as a need for realization in a particular area, the article presents studies about the relationship of dreams with the presence of a disease associated with a particular area of life, and statistically confirms the relationship of psychosomatic diseases from lack of human self-realization in certain sphere of life.

The researches presented in the article open a new perspective on the causes of psychosomatic diseases, their relationship not only in the holistic system of the human body and psyche, but also the relationship of man with his inner feelings and external world through a seven-level model of life. In addition, a cholistic system of internal sensations and external manifestations of man has a causal part in human dreams, which allowed to form a new concept of psychosomatics as causal and system holism.
Сучасна наука (як психологія, так і медицина) в пошуках істини поглибилася у частковості i знайшла безліч важливих деталей для допомоги людині, при цьому втративши важливий момент єднання людини із законами природи. У сучасній психології активно розвивається гуманістичне спрямування, яке бачить розвиток людини через внутрішнє прагнення до вищих цінностей. Одночасно медична наука практично зайшла в глухий кут у пошуках причин хвороби безпосередньо у матеріальності тіла. «Відомо, що офіційна медицина в усіх розвинених країнах уже давно дійшла до тієї межі, за якою стає очевид- ним: колишні методологічні основи здоров'я не дозволяють ні збільшувати середню тривалість життя, ні знижувати дитячу смертність. Для подальшого прогресу в медицині, психологіï i в охороні здоров'я загалом потрібні нові принципи, нові ідеї, нова організаційна структура. Адже в основі своїй офіційна медицина, як i раніше, залишається симптоматичною, вона усуває симптоми і слідства, а не саму хворобу i ii причини» (В. Воронцов, 1995). Саме тому сучасна медицина все більше звертає погляд на зв' язок розвитку соматичних захворювань 3 психікою людини. 
Мета дослідження - теоретично обгрунтувати та експериментально перевірити взаємозв'язок між прагненнями людини в семи сферах життя та наявністю відповідних захворювань.

Згідно 3 даними експертів ВО3, майже 50\% стаціонарних лікарняних ліжок у світі займають пацієнти 3 психосоматичною патологією [2]. Цим питанням займається сучасний напрям медицини - холістична медицина (холі́зм $з$ грец. ő $\lambda$ o (holos) - цілий, увесь), яка розглядає людину цілісно, об'єднуючи традиційні і нетрадиційні методи діагностики i лікування, в тому числі такий суміжний напрям медицини і психології, як психосоматика. Холістичний підхід до здоров'я людини бере до уваги всі потреби пацієнта, не тільки фізичні, але і психологічні, соціальні, і розглядає їх як єдине ціле. У дослідженні 2007 року говориться, що холістична концепція знаходить застосування в первинній медичній допомозі в Швеції [12]. Американська асоціація холістичної медицини стверджує, що в оцінці загального стану хворого необхідно брати до уваги так само i духовні аспекти [13].

Холістичний підхід до терапії захворювань не означає застосування лише альтернативних методів лікування, він враховує всі особливості людини, в тому числі іiі психологічний стан, не виключаючи призначення звичайної терапії. На сучасному етапі холістичний підхід дає принципово нове бачення в можливостях профілактики захворювань як основи нового погляду на медицину в єдності з психологією (En: Integrative medicine) [12].

Концепція, у межах якої психофізіологічна проблема вирішується найбільш повно, базується на теорії функціональних систем П. Анохіна. На погляд цілої низки учених (Б. Ломов, В. Швіркова, К. Платонова, С. Ільїн та інші), підхід до вирішення проблеми співвідношення психології та фізіології став можливим саме на основі теорії функціональних систем, яка пов'язана $з$ вивченням загальних принципів цілісної діяльності організму, де психічне та фізіологічне виступають одне стосовно іншого саме як системні процеси [6].

Незважаючи на зусилля багатьох авторів (Ф. Александер, П. Анохін, Ю. Антропов, А. Венгер, Д. Ісаєв, І. Малкіна-Пих, Н. Маслова, М. Ракітіна, Т. Свиридова, В. Ткачева, Р. Хамер та ін.), не вдається побачити чіткого системного взаємозв'язку між природними законами, психологічним станом і фізичним здоров'ям людини.

Важливим напрямом у наукових дослідженнях холістичного підходу $є$ пошук інтеграційних моделей і причинно-системного аналізу. Сучасний холістичний підхід, поєднуючи частини системи людини в одне ціле, не враховує внутрішньої мети існування людини на основі причинно-наслідкових зв'язків.

При цьому прояви людини у світі припускають дослідження адекватної установки як причини, орієнтує свідомість на творчість багаторівневого прояву особистості «у життєвому просторі і у часовій перспективі» (за К. Левіним) [3]. Грунтуючись на прагненні людини до соціальної актуалізації, Л. Виготський демонструє вищі психічні функції особистості, аргументуючи роль свідомості як творчий початок людини. Л. Виготський писав, що «причинності свідомості приділяється незначна увага сучасною наукою...» [7]. У цьому разі причинно-наслідковий підхід у психологічних дослідженнях може стати основою, що поетапно формує процес моделювання психологічної системи як системи оздоровлення людини.

Особливо цей цілісний підхід та причинно-наслідкові зв'язки глибоко розкриває В. Поляков [8] у створеній ним міждисциплінарній науці універсології (універсум (лат. universum) - філософське поняття, що позначає «світ як ціле» або «все існуюче»). Універсологія - наука, у якій людина розглядається як частина планетарної і вселенської системи, що розвивається за загальними законами світобудови [7; 9].

Синтезуючи досвід світової культури і спираючись на трактати великих мислителів минулого (Платон, Аристотель, К. Юнг, В. Франкл, О. Блаватська, Є. Реріх, А. Бейлі), універсологія показує чіткі взаємозв'язки систем побудови світу з життям людини (в тому числі ії здоров’я) як підсистеми світу: вказуючи на космізм людини, iї внутрішнє прагнення до вищих цінностей, духовного розвитку, потреби в розвитку душі.

Згідно з В. Поляковим, хвороба виникає у разі відхилення життя особистості від внутрішнього завдання душі, яка розглядається як глибинна мрія людини, що є причиною іiі існування і рухає підсвідомістю людини [1; 4].

Таким чином, стає очевидним той факт, що цільова стратегія (мрія людини), як свідоме прагнення до діяльності, є ключовою для особистості, що розвивається. I водночас визначення цільової стратегії є динамічним процесом, в якому відбивається подвійність проявів (за К. Левіним): вольової індивідуальної і польової (колективної) поведінки [3, с. 273]. Факт єдності особистості і навколишнього середовища виражений Левіним у понятті «життєвий простір», що володіє такими властивостями, як рівень реальності і тимчасова перспектива.

Так, введення поняття тимчасової перспективи об'єднало минулий досвід людини та іії майбутнє у вигляді цільової установки (мрії, прагнення до основного завдання життя). Прагнення до вищої мрії в період розвитку людини стимулює досяг- 
нення нового якісного рівня іiі життя, що стане основою не тільки психологічного стану, а й основою оздоровлення людини.

Мрія, мета, сенс життя як багаторівневий мотив розвитку досліджувалися в історії давнини ще Аристотелем, Ф. Аквінським, Августином. У сучасну епоху мета як мотив, як інтенція досліджувалася Левіним, Брентано, Гуссерлем та ін., як сенс - Франклом, Роджерсом, Олпортом та ін.

Такі мрії, що включають вищі цінності людини, мрії про реалізацію свого призначення, пов'язані наприкінці з потребою у зміні світу, суспільства, підвищення культурних і моральних цінностей, можна віднести до вищих мрій. Однак є мрії повсякденні, які пов'язані з реалізацією і задоволенням життя індивідуума. Такі мрії більшою мірою говорять про відсутність реалізації людини в тій чи іншій сфері життя, стимулюють $\dddot{1 i}$ до розвитку і самореалізації. У цьому разі причинно-наслідковий підхід у психологічних дослідженнях може стати основою поетапного формування процесу моделювання психологічної системи як системи оздоровлення людини.

Таким чином, можна стверджувати, що цілісність (холізм) - це не тільки з'єднання частин у ціле (системності людини), а й прагнення до мети буття людини - внутрішньої причини життя, розвитку і реалізації. Таким чином, з'являється нове поняття «причинно-системний холізм» у сфері здоров'я та психології людини.

Універсологія застосовує низку моделей, що показують не тільки вплив системи на людину, а також дають систему причинно-наслідкових зв'язків та відображають взаємодії всередині будь-якої системи, в тому числі вплив багаторівневих психосистемних відношень людини з навколишнім світом через сім сфер життя на її здоров'я.

Вперше про семирічність будови людини i сім енергетичних центрів організму згадується в індійських медичних трактатах, переведених Джоном Вудроффом, більш відомим під ім'ям Артур Авалон. Пізніше зв'язок енергосистеми 3 ендокринними органами описувався у філософ- ських трактатах А. Бейлі та сучасних філософів (Н. Віторська, В. Поляков, А.Е. Хан, та ін.) [1; 7; 11].

Синтез семирівневої моделі світобудови, будови та життедіяльності людини як основи цілеспрямованості життя на гармонію з навколишнім світом провів В. Поляков у створеній ним науці універсології, що розкриває причинно-системну світобудову і практичне застосування знань універсальних закономірностей у всіх галузях людської діяльності і в практиці щоденного життя [8]. В. Поляков описав сутність прояву системи як відносин, що складаються з семи рівнів, де три рівні - це сфера наслідків, наступні три рівні сфера причин, а 4-й рівень - перехідний між ними (рис. 1).

Охарактеризуємо сім сфер життя людини за Поляковим [7]: 1. Фізична сфера (ресурси життя людини: тіло, здоров'я, простір життя, їжа, побутові умови). 2. Емоційна сфера (гармонійність емоційного стану людини). 3. Ментально-діяльна сфера (розумова активність, професійна діяльність). 4. Соціальна сфера (адаптивність у світі, визнання, потрібність іншим людям). 5. Колективна сфера (сталість і надійність у колективі друзів, родичів, сім'і, колег, однодумців). 6. Громадська сфера (вплив на життя суспільства, ціннісні орієнтири людини). 7. Світоглядний рівень (цілі і перспективи життя людини, сенс життя, загальнолюдський рівень).

Позаяк фізичною відповідністю сфер життя в організмі людини $€$ сім основних ендокринних залоз організму, що регулюють діяльність внутрішніх органів і стимулюють внутрішньоклітинні процеси [4; 9], ми побачимо пряму психофізичну залежність захворювань людини від іiі проявів в тій чи іншій сфері життя (табл. 1).

Об'єднуючи сфери життя, ендокринні залози, системи органів у взаємозв'язку з енергоцентром, ми бачимо чіткий алгоритм формування психосоматичної хвороби: спотворення прояву людини в одній зі сфер життя (відхилення від вищої задачі, мрії) формує спотворення в енергоцентрі (чакри), що призводить до зміни

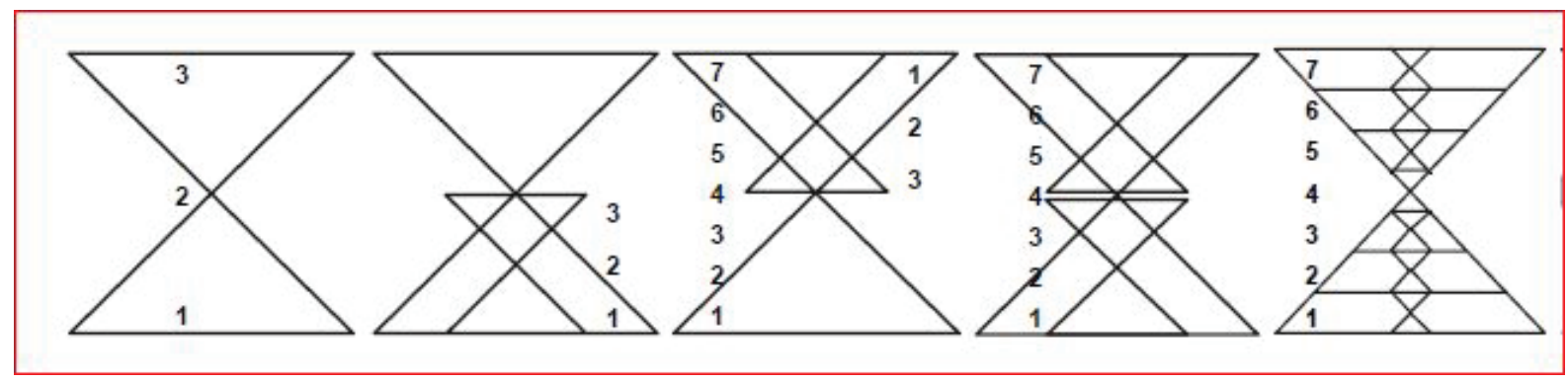

Рис. 1. Сутність семирівневої системи за В. Поляковим 
Таблиця 1

Взаємозв'язки сфер життя людини з ендокринними залозами та системами органів [1]

\begin{tabular}{|l|l|l|}
\hline \multicolumn{1}{|c|}{ Сфера життя } & \multicolumn{1}{|c|}{ Зв'язок з ендокринною залозою } & \multicolumn{1}{|c|}{ Вплив на органи і системи } \\
\hline 1. Фізична сфера & наднирники & сечовидільна система, обмін солей \\
\hline 2. Емоційна сфера & гонади & статева система \\
\hline 3. Ментально-діяльна сфера & підшлункова залоза & шлунково-кишковий тракт \\
\hline 4. Соціальна сфера & вилочкова залоза & $\begin{array}{l}\text { iмунна система, кров, кровотво- } \\
\text { рення, побічно на серцево-судинну } \\
\text { систему }\end{array}$ \\
\hline 5. Колективна сфера & щитовидна залоза & $\begin{array}{l}\text { органи внутрішнього і зовнішнього } \\
\text { дихання: гортань, бронхи, легені, } \\
\text { щитовидна залоза }\end{array}$ \\
\hline $\begin{array}{l}\text { б. Громадська сфера, сфера } \\
\text { цінностей }\end{array}$ & гіпофіз & $\begin{array}{l}\text { периферична нервова система - } \\
\text { управління рухом (суглоби, м'язи), } \\
\text { органи чуття (очі, вуха, шкіра, язик) }\end{array}$ \\
\hline 7. Світоглядна сфера, сфера цілей & епіфіз & $\begin{array}{l}\text { центральна нервова система, пси- } \\
\text { хічний стан людини }\end{array}$ \\
\hline
\end{tabular}

функції ендокринної залози і подальшого гормонального впливу на систему органів, пов'язаних з ендокринною залозою і формуванням спочатку функціональної, а потім органічної зміни в органі (захворювання) [7].

У цьому сенсі $є$ актуальним у цій роботі дослідження взаємозв'язку хвороби людини з ії психологічним станом через універсальну семирівневу модель взаємин людини зі світом, запропоновану міждисциплінарною наукою універсологією.

Для дослідження ми вибрали респондентів 3 числа студентів заочного навчання курсів 3 психосоматики освітнього центру «Школа холістичного здоров'я» і освітнього центру психології «Кристал-Сенс» (м. Дніпро). Група дослідження складалася 340 осіб (38 жінок і 2 чоловіки) віком від 29 до 57 років (середній вік 41,2 року).

Оскільки методика визначення психосоматичних захворювань, узгоджених зі сферами життя людини, і виявлення впливу самореалізації за рівнями використовується уперше, нами була розроблена авторська модель визначення взаємозв'язку між прагненнями людини у семи сферах життя та наявністю захворювань за кожною із семи сфер.

Згідно 3 теоретичними роздумами В. Полякова, спотворений прояв людини в тій або іншій сфері життя може сформувати захворювання саме на цьому рівні прояву людини. Для визначення проявів людини у семи сферах життя нами було запропоновано кожному респонденту оцінити свої сфери життя та визначити свої мрії, які ми також розподілили за семи сферами. Надалі ми порівнювали оцінки 3 наявними захворюваннями на цих сферах. У разі, якщо самооцінка респондента показує незадоволення прояву людини в тій або іншій сфері життя, це означає, що в цій сфері життя людина проявлена дисгармонійно, що, імо- вірно, може бути причиною формування захворювання на цьому рівні. Якщо ж самооцінка буде ілюзорно підвищеною (ідеальною), це означає, що досліджуваний не бачить шляхів подальшого розвитку в цій сфері життя, що, імовірно, так само може формувати сприятливі умови для розвитку захворювань на цьому рівні.

Для цієї методики ми створили опитувальник, в якому запропонували відзначити наявні захворювання, розподіливши їх за семи рівнями (за Поляковим): по два варіанти на кожний рівень усього чотирнадцять варіантів. У другому опитувальнику ми запропонували респондентам поставити оцінку свого прояву в кожній із семи сфер життя, по два варіанти на кожний рівень - усього чотирнадцять варіантів.

У третьому опитувальнику ми запропонували вибрати найбільш важливі мрії, які так само розподілили за семи сферами життя, по дві мрії на кожен рівень, усього чотирнадцять варіантів, у балах від 1 до 10, де 1-2 - жахливо (майже ніяк); 3-4 - погано (украй мало); 5-7 - нормально; 8-9добре; 10 - ідеально (краще не буває). Для дослідження враховувалися збіги оцінок сфер життя від 1 до 4 (жахливо і погано) з наявністю захворювання на цьому рівні, а також збіг оцінок сфери життя на 10 балів (ідеально) як ілюзорно завищеної самооцінки з наявністю захворювань.

Кількість збігів низької або завищеної оцінок сфери життя та наявність мрії порівнювалася 3 наявністю захворювань на цьому рівні та аналізувалася в процентному відношенні. У разі наявності статистичної достовірності методика підтверджує припущення про те, що психосоматичні захворювання людини пов'язані з якістю життя людини та наявністю іï внутрішніх прагнень у семи сферах життя. 
У результаті дослідження ми виявили, що всі $100 \%$ досліджуваних мають симптоми захворювань хоча б на одному рівні. Усі 40 респондентів iз 7 можливих рівнів у кожного (всього 280 можливих варіантів) відзначили наявність захворювань 158 разів, у середньому на кожного респондента доводиться по 4 захворювання (X1=3,95 захворювань). Максимальне число захворювань відзначене на 6 рівні (захворювання суглобів, хребта, органів чуття і периферичної нервової системи) - 37, найрідше зустрічалися симптоми захворювання на 4 рівні (серцево-судинної системи, крові і імунітету) - 14 .

Дослідивши оцінку якості свого життя за семи рівнями, ми виявили, що 90\% (36 респондентів) поставили низьку або ілюзорно завищену оцінку хоч в одній із семи сфер життя, у середньому така оцінка була в 3 сферах у кожного (X2=2,97 сфери).

Зіставляючи наявність захворювань на тому або іншому рівні з наявністю пониженої або завищеної самооцінки на цьому ж рівні, нами визначалося число збігів цих показників за рівнями (табл. 2).

Таким чином, було визначено, що як низька, так і завищена оцінка якості життя (як неможливість подальшого розвитку) має вплив на розвиток захворювання. Кількість низьких оцінок більш впливає на формування захворювання, усього наявність низьких та завищених самооцінок у $69,16 \%$ співпадає з наявністю захворювання на цьому рівні (рис. 2).

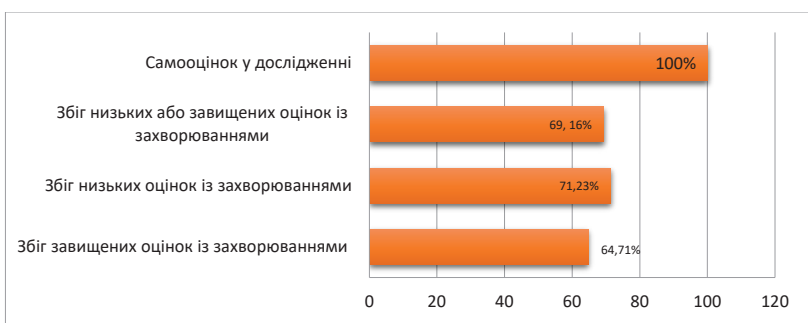

Рис. 2. Відсоток збігів низьких або завищених оцінок із захворюваннями

На цьому етапі нам вдалося визначити статистичну достовірність взаємозв'язку незадоволення та ілюзорного ідеального прояву у сфері життя 3 виникненням симптому або захворювання на рівні цієї сфери життя, що підтверджує взаємозв'язок виникнення захворювань від прояву людини в семи сферах життя $(\mathrm{r}=0.217, \mathrm{p}=0.000258)$.

Другим етапом ми звіряли наявність повсякденної мрії людини з наявністю захворювання на тому рівні, на якому перебувала мрія. Досліджуючи мрії, які відзначили респонденти як найбільш важливі в цей період життя, ми побачили, що максимальне число мріянь пов'язане 3 першою сферою життя - матеріальним благополуччям i фізичним здоров'ям і з третьою сферою - сферою інтересів, професійним розвитком. Але ж у інших сферах життя респонденти також мали потребу в реалізації мрії, хоча менше всього така потреба проявлялася на 4, 5, 6 сферах життя: потреба в реалізації у соціумі, побудова надійних колективних стосунків і вплив на суспільство (рис. 3).

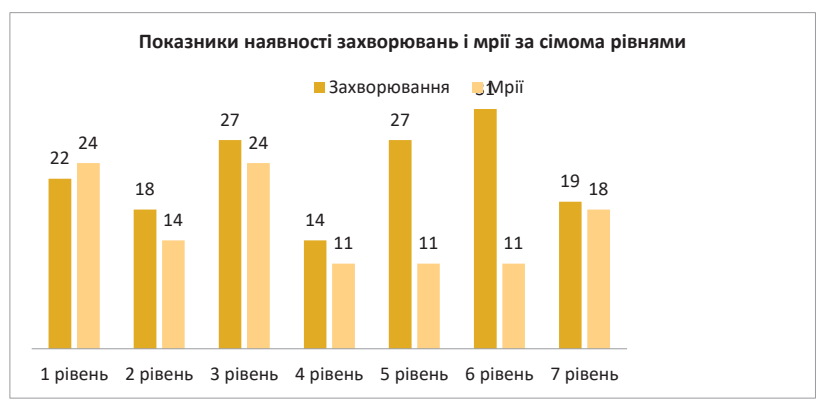

Рис. 3. Показники наявності захворювань і мрії за сімома рівнями

Дивлячись на діаграму, ми бачимо взаємозв'язок між наявністю повсякденної мрії (нереалізованого бажання, потреби) і наявністю захворювання. Такі взаємозв'язки $є$ на 1, 2, 3, 4 та 7 рівнях, але на 5 та 6 рівнях (колективні стосунки5 рівень і громадські стосунки - 6 рівень), незважаючи на невелике число мріянь, на цих рівнях ми бачимо велике число захворювань. Можна припустити, що захворювання показують неусвідомлені бажання людини в реалізації на цих рівнях.

Порахувавши число збігів мрії 3 наявністю захворювання на окремих рівнях у кожного з респондентів, ми побачили збіги в 76,11\%, що говорить про те, що наявність нереалізованої мрії, яка означає, що в цей період відсутня самореалізація

Таблиця 2

Кількісне відсоткове співвідношення самооцінки з наявністю захворювання

\begin{tabular}{|l|c|c|c|}
\hline Оцінок в обробці даних & Кількість оцінок & $\begin{array}{c}\text { Кількість збігів із } \\
\text { захворюваннями }\end{array}$ & 3бігів, \% \\
\hline Низьких & 73 & 52 & 71,23 \\
\hline Завищених & 34 & 22 & 64,71 \\
\hline Всього & 107 & 74 & 69,16 \\
\hline
\end{tabular}


людини в цій сфері життя, майже напевно викликає розвиток захворювання на цьому рівні.

Досліджуючи статистичну достовірність, ми визначили прямий помірний зв'язок $(\mathrm{r}=0,329)$. Число ступенів свободи (f) становить 278. t-критерій Стьюдента дорівнює 5,803. Критичне значення t-критерію Стьюдента при цьому числі ступенів свободи становить 1,972 . ознак статистично значима $(\mathrm{p}=0,000001)$.

Таким чином, наша методика показала статистичну достовірність причинно-системного зв'язку належності мрії (як відсутність реалізованої потреби) 3 виникненням симптому або захворювання на рівні цієї сфери життя, що підтверджує взаємозв'язок виникнення психосоматичних захворювань від відсутності самореалізації людини у певній сфері життя.
Отже, ми статистично достовірно довели зв'язок між некомфортним психологічним станом людини у семи сферах життя та виникненням захворювань, відповідних цим рівням взаємодії людини зі світом; статистично довели залежність наявності захворювання від внутрішнього прагнення до розвитку (повсякденної мрії) людини. Таким чином, ми можемо стверджувати, що тіло через хворобу підсвідомо стимулює людину до розвитку і реалізації внутрішніх потреб, а причина захворювань лежить у сфері реалізації внутрішніх прагнень людини, тому 3 огляду на причинно-системні зв'язки холістичний підхід до здоров'я можна назвати причинно-системним холізмом. Експериментальна перевірка цих припущень і становить перспективу наших подальших досліджень.

\section{ЛІТЕРАТУРА}

1. Виторская Н.М. Причины болезней и истоки здоровья / сост. И.И. Виторский, М.П. Мороз. 6-е изд. Москва : Амрита-Русь, 2008. 264 с. (Серия «Универсология»).

2. Доклад о состоянии здравоохранения в Европе, 2009 г. Здоровье и системы здравоохранения. Новости медищины и фармачии. 2009. № 1-2. С. 5-6.

3. Левин К. Динамическая психология: избранные труды. Москва : Смысл, 2001. 572 с

4. Одинець О.А., Шукалова О.С. Використання семирівневого підходу як природної орієнтації психічного і фізичного здоров’я людини. Харківський осінній марафон психотехнологій: матеріали III міжрегіональної наук.-практ. конф., ХНПУ імені Г.С. Сковороди. Харків : Діса плюс, 2019. 248 с. C. $176-179$

5. Одинець О.А. Проблема ідеалу і ціннісних орієнтирів у вихованні та оздоровленні людини. Універсалії науки та освіти: формування світогляду особистості нової епохи : матеріали 4-ї Міжнародної наук. конф. Чернігів : Десна Поліграф, 2019. 144 с. С. 121-124.

6. Перетятько Л.Г. Психосоматичні розлади: сучасний стан проблеми. Психологія і особистість. 2017. № 2. С. 137-147.

7. Поляков В.А. Универсология. История. Законы. Практика. Минск : ВЭВЭР, 2013. 200 с. (Международная научная школа Универсологии).

8. Поляков В.А. Философия жизни. Путь творения. 2010. 103 с. (Международная научная школа Универсологии).

9. Полякова И.Ю., Поляков В.А. Психосистемология. Минск : ВЭВЭР, 2003. 244 с.

10. Психологическая энциклопедия. Москва-Санкт-Петербург, 2003, с. 974-975.

11. Хан Е.Б. Таинственный семеричный закон и человек. Портал научно-практических публикаиий. 2014. URL: http://portalnp.ru/2014/08/2185 (дата звернення: 11.09.2020).

12. Dictionary of Metaphysical Healthcare. Glossary. Quackwatch. URL: https://quackwatch.org/related/ dictionary/mdglos/ (дата звернення: 12.07.2020).

13. Holistic Medicine. American Cancer Society. URL: https://www.cancer.org/treatment/treatments-andside-effects/complementary-and-alternative-medicine.html (дата звернення: 12.07.2020).

\section{REFERENCES}

1. Vitorskaya, N.M. (2008). Prichiny bolezney i istoki zdorov'ya [Causes of disease and origins of health]/ sost. I.I. Vitorskiy, M.P. Moroz. Moskva: Amrita-Rus' (Seriya “Universologiya") [in Russian].

2. Doklad o sostoyanii zdravookhraneniya v Yevrope, $2009 \mathrm{~g}$. Zdorov'ye i sistemy zdravookhraneniya. Novosti meditsiny i farmatsii [The European health report 2009: Health and health systems]. No1 [in Russian].

3. Levin, K. (2001). Dinamicheskaya psikhologiya: Izbrannyye trudy. Moskva: Smys1 [in Russian].

4. Odynets, O.A., Shukalova, A.S. (2019). Ispol'zovaniye simirivnevogo podkhoda kak yestestvennoy oriyentatsii psikhicheskogo i fizicheskogo zdorov'ya cheloveka. Khar'kovskiy osennyi marafon psikhotekhnologiy: materialy III mezhregional'noy nauchno-prakticheskoy. konf., KHNPU imeni G.S. Skovorody. [The use of a seven-level approach as a natural orientation of mental and physical health]. Khar'kov: Disa plyus [in Ukrainian]. 
5. Odynets', O.A. (2019). Problema idealu i tsinnisnykh oriyentyriv u vykhovanni ta ozdorovlenni lyudyny. Universaliyi nauky ta osvity: formuvannya svitohlyadu osobystosti novoyi epokhy: materialy 4-yi Mizhnarodnoyi nauk. konf. [The problem of the ideal and values in the education and rehabilitation of man. Universals of science and education: the formation of the worldview of the individual of the new era]. Chernihiv: Desna Polihraf [in Ukrainian].

6. Peretyat'ko L.H. (2017). Psykhosomatychny rozlady: suchasnyy stan problemy. Psykholohiya i osobystist' [Psychosomatic disorders: the current state of the problem. Psychology and personality]. No. 2 [in Ukrainian].

7. Polyakov, V.A. Unyversolohyya. (2013). Ystoryya. Zakony. Praktyka [Universology. History. Laws. Practice]. Mynsk: VÉVÉR (Mezhdunarodnaya nauchnaya shkola Unyversolohyy) [in Russian].

8. Polyakov, V.A. (2010). Fylosofyya zhyzny. Put' tvorenyya [Philosophy of life. The path of creation]. (Mezhdunarodnaya nauchnaya shkola Unyversolohyy) [in Russian].

9. Polyakova I.Yu., Polyakov V.A. (2003). Psikhosistemologiya [Psychosystemology]. Minsk: VEVER [in Russian].

10. Psikhologicheskaya entsiklopediya. (2003). [Psychological encyclopedia]. Moskva-Sankt-Peterburg [in Russian].

11. Khan, Ye.B. (2014). Tainstvennyy semerichnyy zakon i chelovek. Portal nauchno-prakticheskikh publikatsiy [The mysterious sevenfold law and man. Portal of scientific and practical publications]. Retrieved from: http://portalnp.ru/2014/08/2185 [in Russian].

12. Dictionary of Metaphysical Healthcare. Glossary. Quackwatch. Retrieved from: https:/quackwatch.org/ related/dictionary/mdglos/ [in English].

13. Holistic Medicine. American Cancer Society. Retrieved from: https://www.cancer.org/treatment/treatments-and-side- effects/complementary-and-alternative-medicine.html [in English]. 